\title{
STUDY ON THE EFFECTS OF METHYL PREDNISOLONE AS PULSE THERAPY IN PATIENTS WITH TUBERCULOUS MENINGITIS IN RIMS RANCHI, JHARKHAND, INDIA
}

\section{Neelam Kumari \\ Chandra Bhushan Sharma}

Rishi tauhin Guria

Sanjay Kumar*
Senior Resident, Department of Medicine, Rajendra Institute of Medical Sciences (RIMS), Ranchi.

Professor, Department of Medicine, Rajendra Institute of Medical Sciences (RIMS),Ranchi.

Associate Professor, Department of Medicine, Rajendra Institute of Medical Sciences (RIMS),Ranchi.

Associate Professor, Department of Forensic Medicine and Toxicology, Rajendra Institute of Medical Sciences (RIMS), Ranchi. *Corresponding Author

ABSTRACT The common presentation of tuberculosis is common but uncommon presentation of tuberculosis is not so uncommon. Mycobacterium tuberculosis can affect any part of the body, at any age and in any form. Tuberculous meningitis (TBM) is a serious form of tuberculosis that affects meninges (coverings of brain and spinal cord) which are responsible for many deaths ${ }^{(1)}$. It is associated with high mortality and morbidity. The steroids appear to reduce mortality in the patients of tuberculous meningitis, regardless of the MRC stage at presentation. Corticosteroids have been used as an adjunct to anti-tuberculous drugs to treat patients with tuberculous meningitis ${ }^{(3,4,5,6)}$. The present study has been undertaken to evaluate the effects of short course, high dose of intravenous methylprednisolone (pulse therapy) versus intravenous dexamethasone (in conventional dose) as an adjunct to anti-tuberculous treatment, on the clinical, biochemical and radiological outcome in patients with tuberculous meningitis A total of 94 TBM patients were enrolled for this study. 49 TBM patients as a case were given IV infusion of high dose methylprednisolone ( $\mathrm{lg} /$ day for 5 days) and forty five TBM patients as control were given IV dexamethasone in conventional dose $(0.4 \mathrm{mg} / \mathrm{kg} /$ day divided in $3-4$ doses) along with antituberculous therapy. Detailed clinical, biochemical, microbiological and radiological evaluation were performed and findings were evaluated. TBM is considered as a serious extrapulmonary form of TB (Tuberculosis) and should arise suspicion in mind of clinicians based on clinical findings for prompt diagnosis and treatments. In various studies it has been shown that corticosteroids used for longer periods in TBM patients along with antituberculous drugs, were associated with reduced mortality and morbidity but increased adverse effects. In the present study, methylpredisolone used as a pulse therapy showed significant improvement in clinical profile, laboratory findings and radiological outcome.

KEYWORDS : Tuberculous meningitis (TBM), pulse therapy, steroids, incidence and prevalence, laboratory parameters,

\section{INTRODUCTION}

The common presentation of tuberculosis is common but uncommon presentation of tuberculosis is not so uncommon. Mycobacterium tuberculosis can affect any part of the body, at any age and in any form. Tuberculous meningitis (TBM) is a serious public health problem in developing countries, as it leads to significant mortality and residual neurological morbidity. Despite India being an endemic country for TB, data regarding clinical, laboratory and biochemical parameters and final outcome of adult TBM patients is sparse. Analysis of such variables in various countries has shown association of various factors with prognosis of the disease like age, stage of disease, level of consciousness, presence of extra neural TB, isolation of mycobacterium tuberculosis from CSF, biochemical studies and hydrocephalous ${ }^{(7-9)}$. The availability of such data in high burdened developing country like India may help in prediction of the prognosis of such patients, and help in the early intervention of preventive measures to improve the subsequent outcome of the patient. Without antitubercular treatment, patients with tuberculosis are likely to die sooner ${ }^{(1,10)}$.

Corticosteroids are cornerstone in the management of $\mathrm{TBM}^{(19)}$. Corticosteroids reduce the number of deaths and prevent disabling neurological deficits in patients with $\mathrm{TBM}^{(2,11-18)}$. The steroid protocol followed by Thwaites' et.al. is widely used in clinical practice. However, this fixed regime for IV steroids for 2-4 weeks requires a long hospital stay. Because TBM mostly affects people from poor socio-economic backgrounds, many of these patients cannot afford a long hospital stay. Here, we followed a different protocol to rapidly taper IV steroids use in patients with TBM. The objectives of present study were planned to assess the clinical profile, laboratory value and radiological features of adult TBM patients after intervention as pulse therapy of IV methylprednisolone given for short period (case), and their outcomes were compared with dexamethasone group (control).

\section{MATERIAL AND METHODS}

This is a randomized controlled and interventional study. Inclusion criteria... Two hundred and fifty patients, diagnosed with tuberculous meningitis and admitted in the Department of Internal Medicine, Rajendra Institute of Medical Sciences (RIMS), Ranchi, Jharkhand, India from April 2019 to July 2020 were examined and after exclusion of 156 TBM patients, a total of 94 patients were included for this study.

Exclusion criteria... Patients diagnosed with HIV, diabetes or other immuno-compromised status, unable to perform laboratories and radiological examinations, unwilling to be included in the study with consent were excluded from the study.

Data collection and interpretation

Out of total 250 patients, after exclusion of 156 patients on aforesaid exclusion criteria, a total of 94 adult patients diagnosed as TBM based on clinical criteria with consent were enrolled for present study. All these patients fulfilled Thwaites index of scoring for TBM diagnosis ${ }^{(20)}$. Clinical staging (stage 1 to stage 3 ) of patients were done using medical research council staging system ${ }^{(21)}$. The patients were divided randomly 
into case (methylprednisolone) and control (dexamethasone) groups. The case group included 49 TBM patients and control group included 45 TBM patients. Detailed clinical history including demographic data (age, gender), presenting complains (fever, headache, vomiting, convulsions, altered sensorium, visual impairment, focal weakness) and duration of illness were recorded. Clinical examination of patients was done and recorded.

Laborateries and radiological evaluations were performed including hemogram, blood sugar, $\mathrm{HbAl} \mathrm{c}$, serum-Na+, $\mathrm{K}+$, $\mathrm{Ca}++$ and $\mathrm{Mg}++$, renal and liver function tests, urine analysis, serological study, chest X-ray, electrocardiogram and pregnancy test, before start of therapy. For CSF examination, lumbar puncture with full aseptic precaution was done and sent immediately to laboratory for analysis. For radiological diagnosis contrast enhanced computed tomography and magnetic resonance imaging (MRI) study (if needed) were done. MRI has better resolution for infarct and tuberculoma. The common brain imaging features in TBM were basal exudate, tuberculoma, infarct and hydrocephalous (11).

\section{Intervention}

The 94 TBM patients, included in the present study were divided into two gropus, methylprednisolone (N-49,case) and dexamethasone (N-45,control) groups. The case was given IV pulse therapy for five days and control was given IV dexamethasone in conventional dose and their outcome were evaluated and compared. Methylprednisolone was given as $\mathrm{lg} /$ day IV infusion as pulse for five days. Vitals monitoring were done every 30 min during infusion. Blood sugar and serum electrolytes were done alternate day. Any abnormalities detected were corrected accordingly. Dexamethasone in control group was used as $0.4 \mathrm{mg} / \mathrm{kg} / \mathrm{day}$ in 3-4 divided doses till sustained relief in patients' symptoms were achieved.

After five days of treatments, clinical, biochemical and radiological outcome between both groups of patients were measured and findings were evaluated and analysed on seventh day. Patients of both groups who exhibited sustained improvement in clinical profile were discharged with oral steroids in tapering dose for 4 weeks along with antituberculous drugs and kept on regular follow up. Average days of IV dexamethasone injection were more than nine days.

\section{Statistical Analysis}

SPSS16 statistical software has been used for data analysis. Kosmogorov-Smirnov test was used for coherence of normal distribution of variables. Student t-test has used in pair wise group analysis of continuous variables which were normally distributed and data were represented as mean \pm standard deviation. Mann Whitney $\mathrm{U}$ test was used in pair wise analysis of continuous and ordinal variables, which were not normally distributed, and the data were represented as median (quarters of 25-75\%), categorical data was compared using Pearson's Chi square test and was represented as numberspercentages. P values less than 0.05 were considered statistically significant.

\section{RESULTS}

Statistical analysis was done using SPSS version 16. P-value of $<0.05$ was considered to be statistically significant. Baseline characteristics of both groups at the time of enrolment were comparable. There was no statistically significant difference in demographic data, clinical profile, laboratory findings and radiological parameters between both groups ( $p$-value $>0,05$ ). After intervention in the methylprednisolone group, significant improvement were observed in clinical, biochemical and radiological profile in the patients with reduced days of hospital stay.

Baseline characteristics of case and control groups at the time of enrolment as presented in table-1, shows that the mean age of case and control patients was 43.7 and 40.6 years respectively. The case patients comprised $28.6 \%$ females and $71.4 \%$ males while the control groups of patients comprised $35.6 \%$ female and $64.4 \%$ males. There was no statistical significant difference in age and gender of both groups $(\mathrm{p}>0.05)$.

The duration of symptoms in all TBM patients was more than 6 days with mean \pm SD of $23.333 \pm 14.339$ and $28.289 \pm 18.779$ days in case and control respectively. The most common symptoms in both groups were fever $(87.8 \% \& 97.8 \%)$, headache $(93.9 \%$ \& $99.0 \%)$, vomiting $(79.6 \%$ \& $77.8 \%)$ convulsion (36.7\% \&42.2\%), visual impairment (51\% \& 44.4\%), loss of weight $(79.6 \% \& 80 \%)$ and altered sensorium $(91.8 \% \& 91.9 \%)$ respectively. Past history of TB was present in $36.7 \%$ and $37.8 \%$ and history of contact was present in $24.5 \%$ and $20 \%$ respectively in case and control groups. However, there were no statistically significant differences in the symptoms, past history of TB and history of contact with TB patients in both groups $(\mathrm{p}>0.05)$.

The cranial nerve palsy was present in $42.9 \%$ in case and $44.4 \%$ in control. In both groups, the $6^{\text {th }}$ nerve was the most commonly involved cranial nerve. Most of the patients were presented in stage 3 with mean GCS score 8.225 and 7.756 respectively in case and control. Majority of the patients were dependent for their needs at the time of admission with $\mathrm{mRS}$ score 3-5.

Table-1. Baseline characteristics of TBM patients at the time of enrolment of the study.

\begin{tabular}{|c|c|c|c|c|c|}
\hline \multicolumn{3}{|c|}{ Variables } & \begin{tabular}{|c|} 
Methylpredn \\
isolone \\
Group \\
(Case,N-49)
\end{tabular} & \begin{tabular}{|c|} 
Dexameth \\
asone \\
Group \\
(Control,N \\
$-45)$
\end{tabular} & P-value \\
\hline \multirow[t]{2}{*}{$\begin{array}{c}\text { Demograp } \\
\text { hy }\end{array}$} & \multicolumn{2}{|c|}{$\begin{array}{c}\text { Age } \\
(\text { Mean } \pm \text { SD)yea } \\
\text { rs }\end{array}$} & $\begin{array}{c}43.694 \pm 18.0 \\
86\end{array}$ & $\begin{array}{c}40.578 \pm 15 \\
.402\end{array}$ & $0.373^{@}$ \\
\hline & \multicolumn{2}{|c|}{ Male (N.,\%) } & 35 (71.4\%) & $29(64.4 \%)$ & $0.468^{\#}$ \\
\hline \multirow[t]{14}{*}{$\begin{array}{l}\text { Clinical } \\
\text { Profile }\end{array}$} & \multicolumn{2}{|c|}{$\begin{array}{c}\text { Duration of } \\
\text { Illness ( } \\
\text { Mean } \pm \text { SD)day } \\
\text { s }\end{array}$} & $\begin{array}{c}23.333 \pm 14.3 \\
39\end{array}$ & $\begin{array}{c}28.289 \pm 18 \\
.779\end{array}$ & $0.151^{\Theta}$ \\
\hline & \multicolumn{2}{|c|}{ Fever $(\mathrm{N}, \%)$} & $43(87.8)$ & $44(97.8)$ & $0.064^{\#}$ \\
\hline & \multicolumn{2}{|c|}{$\begin{array}{l}\text { Headache } \\
(\mathrm{N}, \%)\end{array}$} & 46 (93.9\%) & $45(100 \%)$ & $0.092^{\#}$ \\
\hline & \multicolumn{2}{|c|}{ Vomitting $(\mathrm{N}, \%)$} & $39(79.6 \%)$ & $35(77.8 \%)$ & $0.830^{\#}$ \\
\hline & \multicolumn{2}{|c|}{$\begin{array}{c}\text { Convulsion } \\
(\mathrm{N}, \%)\end{array}$} & $18(36.7 \%)$ & $19(42.2 \%$ & $0.586^{\#}$ \\
\hline & \multicolumn{2}{|c|}{$\begin{array}{c}\text { Vision } \\
\text { Impairmen } \\
(\mathrm{N}, \%) \mathrm{t}\end{array}$} & $25(51 \%)$ & $20(44.4 \%)$ & $0.479^{\#}$ \\
\hline & \multicolumn{2}{|c|}{$\begin{array}{c}\text { Weight Loss } \\
(\mathrm{n}, \%)\end{array}$} & $39(79.6 \%)$ & $36(80 \%)$ & $0.961^{\#}$ \\
\hline & \multicolumn{2}{|c|}{$\begin{array}{c}\text { Altered } \\
\text { Sensorium } \\
(\mathrm{N}, \%)\end{array}$} & $45(91.8 \%)$ & $41(91.9 \%)$ & $0.900^{\#}$ \\
\hline & \multirow{2}{*}{$\begin{array}{c}\text { Stage } \\
\text { of TBM } \\
(\mathrm{N}, \%) \\
\end{array}$} & 2 & $4(8.2 \%\}$ & $3(6.7 \%)$ & \multirow[t]{2}{*}{$0.782^{\#}$} \\
\hline & & 3 & $45(91.8 \%)$ & $42(93.3 \%)$ & \\
\hline & \multicolumn{2}{|c|}{$\begin{array}{c}\text { GCS score } \\
(\text { Mean } \pm \text { SD) }\end{array}$} & $8.225 \pm 2.275$ & $\begin{array}{c}7.756 \pm 1.9 \\
32\end{array}$ & 0.286 \\
\hline & \multirow{3}{*}{$\begin{array}{c}\text { Paresis } \\
(\mathrm{N}, \%)\end{array}$} & Hemi & $22(44.9 \%)$ & $18(40 \%)$ & \multirow[t]{3}{*}{$0124^{\#}$} \\
\hline & & Para & $4(8.2 \%)$ & $0(0 \%)$ & \\
\hline & & Quadri & $1(2 \%)$ & $0(0 \%)$ & \\
\hline
\end{tabular}




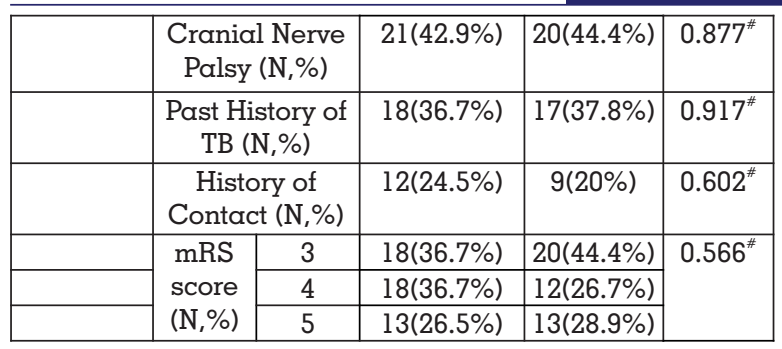

SD-Standard Deviation,TBM-Tuberculous Meningitis, GCSGlasgow Coma score, mRS- modified Rankin Score,@Student t-test,\#-Chi Square test,

The patients with higher mRS score usually represented stage 3 of TBM and they were the sickest of the TBM patients.

On cerebrospinal fluid analysis, the mean CSF cell count in case and control were $180.82 \mathrm{cells} / \mathrm{mm}^{3}$ and $199.84 \mathrm{cells} / \mathrm{mm}^{3}$ respectively. Mean CSF lymphocytes was $89 \%$, mean CSF protein and sugar in case were $235.00 \mathrm{mg} / \mathrm{dl}$ and $31.31 \mathrm{mg} / \mathrm{dl}$ respectively. The below table-2, shows that no statistically significant difference was observed in CSF cell count, lymphocytes, protein and sugar between two groups.

Table-2. The Laboratory findings at the time of enrolment

\begin{tabular}{|c|c|c|c|c|}
\hline & Variables & $\begin{array}{c}\text { Methylpredniso } \\
\text { one Group } \\
\text { (Case,N-49) }\end{array}$ & $\begin{array}{c}\text { Dexamet } \\
\text { hasone } \\
\text { Group } \\
\text { (Control, } \\
\text { N-45) }\end{array}$ & $\begin{array}{c}\mathrm{P}- \\
\text { value }\end{array}$ \\
\hline \multirow[t]{4}{*}{$\begin{array}{c}\text { CSF } \\
\text { Findings }\end{array}$} & $\begin{array}{c}\text { WBC } \\
\text { count(cell/mm3) }\end{array}$ & $180.82 \pm 89.26$ & $\begin{array}{c}199.84 \\
\pm 134.34 \\
\end{array}$ & $0.417^{@}$ \\
\hline & Lymphocytes(\%) & $89.00 \pm 9.57$ & $\begin{array}{c}87.96 \pm 9 \\
19\end{array}$ & $0.280^{@}$ \\
\hline & Protein(mg/dl) & $235.00 \pm 215.63$ & $\begin{array}{c}246.13 \pm 2 \\
07.25\end{array}$ & $0.591^{\circledR}$ \\
\hline & Sugar(mg/dl) & $31.31 \pm 11.06$ & \begin{tabular}{|c|}
$28.98 \pm 10$ \\
.54
\end{tabular} & $0.309^{\circledR}$ \\
\hline
\end{tabular}

CSF-Cerebrospinal fluid, WBC-White Blood Cell count,@Student t-test,

On radiological analysis as presented in table-3, the CT/MRI findings were suggestive of TBM in $73(77.65 \%)$ patients (38 case $77.55 \%$ and 35 control $77.77 \%$ ). Most common radioimaging findings were basal exudates and infarcts. However, statistically no significant differences were present between them.

Table-3. Baseline radiological findings of TBM patients.

\begin{tabular}{|c|c|c|c|c|}
\hline \multicolumn{2}{|c|}{ Variables } & $\begin{array}{c}\text { Methylpred } \\
\text { nisolone } \\
\text { Group } \\
\text { (Case,N-49) }\end{array}$ & $\begin{array}{c}\text { Dexameth } \\
\text { asone } \\
\text { Group } \\
\text { (Control,N- } \\
45)\end{array}$ & $\begin{array}{c}\text { P- } \\
\text { value }\end{array}$ \\
\hline $\begin{array}{c}\text { Radio } \\
\text { Imaging(no, } \\
\%)\end{array}$ & Tuberculoma & $6(12.2 \%)$ & $3(6.7 \%)$ & $0.359^{\#}$ \\
\cline { 2 - 5 } & $\begin{array}{c}\text { Basal } \\
\text { exudates }\end{array}$ & $20(40.8 \%)$ & $16(35.6 \%)$ & $0.600^{\#}$ \\
\cline { 2 - 5 } & $\begin{array}{c}\text { Hydrocephalo } \\
\text { us }\end{array}$ & $12(24.5 \%)$ & $8(17.8 \%)$ & $0.427^{\#}$ \\
\cline { 2 - 5 } & Infarcts & $23(46.9 \%)$ & $23(51.1 \%)$ & $0.686^{\#}$ \\
\hline
\end{tabular}

\#-Chi Square test.

After intervention with IV methylprednisolone infusion as pulse therapy for five days, significant improvement in clinical profile, biochemical findings and radiological outcome were observed and is presented in the table-4. The study revealed statistically significant improvements in methylprednisolone group in terms of clinical symptoms (fever, headache, vomiting, convulsion, stage of TBM, GCS score) as well in CSF and radioimaging findings as compared to dexamethasone group $(p<0.05)$. The study also showed better improvements in vision impairment, sensorium, cranial nerve palsy and $\mathrm{mRS}$ score in case groups in comparison to control groups, however they were not statistically significant. No improvement was observed in degree of paresis in either group.

The repeat radioimaging findings after intervention showed statistically significant disappeance of basal exudates in case groups but no statistically significant difference was observed in number of tuberculoma, degree of hydrocephalous and size of infarcts in both groups.

Table-4. Results of the Clinical profile, laboratory changes and radiological findings after pulse intervention.

\begin{tabular}{|c|c|c|c|c|c|}
\hline & \multicolumn{2}{|c|}{ Variables } & $\begin{array}{c}\text { Methylpredni } \\
\text { solone } \\
\text { Group } \\
\text { (Case,N-49) }\end{array}$ & \begin{tabular}{|c|} 
Dexameth \\
asone \\
Group \\
Control,N- \\
$45)$
\end{tabular} & $\begin{array}{c}\text { P- } \\
\text { value }\end{array}$ \\
\hline \multirow{16}{*}{\begin{tabular}{l|} 
Clinical \\
Findings
\end{tabular}} & \multicolumn{2}{|c|}{ Fever $(\mathrm{N}, \%)$} & $7(14.3 \%)$ & $15(33.3 \%)$ & 0.029 *\# \\
\hline & \multicolumn{2}{|c|}{$\begin{array}{l}\text { Headache } \\
(\mathrm{N}, \%)\end{array}$} & $9(18.4 \%)$ & $24(53.3 \%)$ & $0.000^{* \#}$ \\
\hline & \multicolumn{2}{|c|}{$\begin{array}{c}\text { Vomitting } \\
(\mathrm{N}, \%)\end{array}$} & $7(14.3 \%)$ & $15(33.3 \%)$ & $0.029^{* \#}$ \\
\hline & \multicolumn{2}{|c|}{$\begin{array}{c}\text { Convulsion } \\
(\mathrm{N}, \%)\end{array}$} & $2(4.1 \%)$ & $\mid 12(26.7 \%)$ & $0.002^{* \#}$ \\
\hline & \multicolumn{2}{|c|}{$\begin{array}{c}\text { Vision } \\
\text { Impairment } \\
(\mathrm{N}, \%)\end{array}$} & $5(10.2 \%)$ & $10(22.2 \%)$ & $0.112^{\#}$ \\
\hline & \multicolumn{2}{|c|}{$\begin{array}{c}\text { Altered } \\
\text { Sensorium } \\
(\text { no,\%) }\end{array}$} & $6(12.2 \%)$ & 14(31.1\%) & $0.058^{\#}$ \\
\hline & \multirow{3}{*}{$\begin{array}{c}\text { Stage } \\
\text { of TBM } \\
(\mathrm{N}, \%)\end{array}$} & 1 & $6(12.2 \%)$ & $2(4.4 \%)$ & \multirow[t]{3}{*}{$0.000^{* *}$} \\
\hline & & 2 & $30(61.2 \%)$ & $5(11.1 \%)$ & \\
\hline & & 3 & $13(26.5 \%)$ & 38(84.4\%) & \\
\hline & \multicolumn{2}{|c|}{$\begin{array}{c}\text { Improvement } \\
\text { in GCS score } \\
(\text { Mean } \pm \text { SD) }\end{array}$} & $11.755 \pm 2.278$ & $\begin{array}{c}9.378 \pm 1.9 \\
46\end{array}$ & $0.000^{* @}$ \\
\hline & \multirow{3}{*}{$\begin{array}{c}\text { Paresis } \\
(\mathrm{N}, \%)\end{array}$} & Hemi & $22(44.9 \%)$ & $18(40 \%)$ & \multirow{3}{*}{$0.183^{\#}$} \\
\hline & & Para & $4(8.2 \%)$ & $0(0 \%)$ & \\
\hline & & Quadri & $1(2 \%)$ & $0(0 \%)$ & \\
\hline & \multicolumn{2}{|c|}{$\begin{array}{c}\text { Cranial Nerve } \\
\text { Palsy (no,\%) }\end{array}$} & $10(20.4 \%)$ & $\mid 13(28.9 \%)$ & $0.339^{\#}$ \\
\hline & \multirow{2}{*}{\begin{tabular}{|c|}
$\mathrm{mRS}$ \\
score \\
$(\mathrm{N}, \%)$ \\
\end{tabular}} & 2 & $25(51.0 \%)$ & $27(60.0 \%)$ & \multirow[t]{2}{*}{$0.382^{\#}$} \\
\hline & & 3 & $24(49.0 \%)$ & $18(40.0 \%)$ & \\
\hline \multirow{4}{*}{\begin{tabular}{|c|} 
CSF \\
Findings \\
$($ Mean \pm SD \\
)
\end{tabular}} & \multicolumn{2}{|c|}{$\begin{array}{c}\text { WBC } \\
\text { (cell/ } / \mathrm{mm}^{3} \text { ) }\end{array}$} & $47.14 \pm 38.81$ & $\begin{array}{c}131.42 \pm 10 \\
9.40\end{array}$ & $0.000^{* @}$ \\
\hline & \multicolumn{2}{|c|}{$\begin{array}{c}\text { Lymphocytes( } \\
\%)\end{array}$} & $42.20 \pm 7.04$ & \begin{tabular}{|c|}
$70.84 \pm 7.8$ \\
2
\end{tabular} & $0.000^{* @}$ \\
\hline & \multicolumn{2}{|c|}{ Protein(mg/dl) } & $84.57 \pm 58.80$ & \begin{tabular}{|c|}
$185.71 \pm 17$ \\
1.08
\end{tabular} & 0.000 *@ \\
\hline & \multicolumn{2}{|c|}{ Sugar(mg/dl) } & $52.59 \pm 7.55$ & \begin{tabular}{|c|}
$36.35 \pm 8.9$ \\
2
\end{tabular} & $0.000^{* @}$ \\
\hline $\begin{array}{c}\text { Radio } \\
\text { Imaging } \\
(\mathrm{N}, \%)\end{array}$ & \multicolumn{2}{|c|}{$\begin{array}{c}\text { Disappearanc } \\
\text { e of Basal } \\
\text { exudates }\end{array}$} & $3(6.1 \%)$ & $10(22.2 \%)$ & $0.024^{\star \#}$ \\
\hline
\end{tabular}

SD-Standard Deviation,TBM-Tuberculous Meningitis, GCSGlasgow Comma Scale, mRS- modified Rankin Score, CSFCerebrospinal fluid, WBC-White Blood Cell count, * Statistically Significant, @-Student t-test,\#-Chi Square test.

In the present study, the duration of intervention in case group with IV methylprednisolone infusion for five days was significantly lesser than the number of days $(9 \pm 1.18$ days) 
needed for IV dexamethasone infusion in the control group (table-5). The study also revealed that, the patients of case group were discharged from hospital only in mean 7 days whereas control group needed 10 days (mean) to be discharged, which represented statistically significant reduction $(p<0.05)$ in number of days of hospital stay after intervention with pulse therapy in case group.

Among all the TBM patients included in the present study, $13.83 \%$ died during the study period. However, among the deaths $4.25 \%$ happened within two days of admission and another $3.2 \%$ patients died on the third days of admission. Most of the deaths were because of patients presented in the later stage of TBM. Five patients had disseminated tuberculosis.

Table-5. Comparison of case and control after intervention.

\begin{tabular}{|c|c|c|c|}
\hline Variables & $\begin{array}{c}\text { Methylprednisolo } \\
\text { ne Group } \\
\text { (Case,N-49) }\end{array}$ & $\begin{array}{c}\text { Dexamethasone } \\
\text { Group (Control,N- } \\
45)\end{array}$ & P-value \\
\hline $\begin{array}{c}\text { No. of IV } \\
\text { days } \\
\text { (Mean } \pm \text { SD) }\end{array}$ & $5 \pm 00$ & $9 \pm 1.18$ & $0.000^{\star \star}$ \\
\hline $\begin{array}{c}\text { Duration of } \\
\text { Hospital Stay } \\
\text { (Mean } \pm \text { SD) }\end{array}$ & $7.28 \pm 1.96$ & $10.00 \pm 5.36$ & $0.001^{\star @}$ \\
\hline No. of Deaths & $6(12.2 \%)$ & $7(15.6 \%)$ & $0.642^{\#}$ \\
\hline
\end{tabular}

*- Statistically Significant, @-Student t-test,\#-Chi Square test. t-Mann Whitney U test

\section{DISCUSSION}

Tuberculosis is major global health problem and remains a major public health issue in India. Mycobacterium tuberculosis can affect any part of the body, at any age in any way but when the brain is involved, the consequences are devastating. Around 1 lakh such new cases appearing every year around the world (2). In 2017, eight countries including India, accounted for two-thirds of all TB cases ${ }^{(18)}$.

Tuberculous meningitis that affects meninges of brain and spinal cord, causing fever, headache, vomiting, altered conscious level, visual impairment, convulsion, paresis, coma and death(22). It is caused by infection with one of several mycobacterial species that belong to mycobacterium tuberculosis complex, which are responsible for tuberculosis disease (TB). It is a form of extra pulmonary TB. It is diagnosed clinically, with confirmation by microscopy and culture of cerebral spinal fluids (CSF) or polymerase chain reaction (PCR) test. The clinical outcome is often poor even when patients with tuberculous meningitis are treated with antituberculous drugs. Early diagnosis and prompt treatment are the main determinants of a good outcome in patients with tuberculous meningitis ${ }^{(23)}$.

The causes of disability and death in tuberculous meningitis are multifactorial. The main pathological mechanism are persistent or progressive rise in intracranial pressure with or without hydrocephalus, involvement of the optic nerves or optic chiasma leading to visual impairment, cranial neuropathies, arachnoiditis, and vasculitis of the cerebral blood vessels leading to stroke.

With the advent of newer antituberculous drugs- isoniazid, rifampicin, ethambutol and pyrazinamide-are associated with better survival. Reports of mortality rates vary from $20 \%$ to $32 \%$ and permanent neurological disability in additional 5$40 \%$ of patients who survive tuberculous meningitis ${ }^{(26-29)}$.

Corticosteroids are commonly used in addition to antituberculous drugs for treating patients with tuberculous meningitis. Corticosteroids help to reduce inflammation of the surface of the brain and associated blood vessels, thereby reducing cerebral and spinal cord oedema and decreasing pressure inside the brain $(24,25)$, reducing inflammation of small blood vessels and damage due to blood flow slowing to the underlined brain tissue, thus reducing the disability and risk of death. However, although corticosteroids may save the lives of some patients who have severe tuberculous meningitis, they may not necessarily improve their quality of life, as some patients may survive but be left with severe disability, rendering them bed ridden and highly dependent.

Pulse therapy is used as an intermittent intravenous infusion of very high doses of corticosteroid over a short period, with the advantage of minimizing the adverse effects of conventional corticosteroid therapy, to achieve a faster response and stronger efficacy and to decrease the need for long-term use of systemic corticosteroids, which is associated with more adverse effects like increased infection, gastrointestinal bleeding, hypothermia, dyselectrolytemia, hyperglycemia, hypertention ${ }^{(11,13,15,17,18,26-28)}$.They mediate their actions through genomic and nongenomic methods ${ }^{(29)}$.

Methylprednisolone is an intermediate acting, potent, antiinflammatory agent with a low tendency to induce sodium and water retention. Its biological half-life is $12-36 \mathrm{~h}$, potency 1.25 times compared with prednisolone. Dexamethasone is a floridated glucocorticoid, with a long half-life of $36-72 \mathrm{hrs}$. It is 6.7 times more potent than prednisolone with no sodium retaining tendency.

In the present study, we found that IV steroids infusion days can be reduced from Thwaites' protocol of 14 days in stage 1 and 28 days in stage 2 and 3 . By reducing the total IV steroids infusion days, overall hospitalisation days can be reduced. The overall, IV steroiods days in methylprednisolone group were mean five days and dexamethasone group were mean nine days with reduced number of days of hospital stay, more with case. It has also been found that after intervention as pulse therapy, TBM patients' morbidity can be markedly reduced with improvement in quality of life.

\section{CONCLUSION:}

From this study, it has been revealed that duration of IV steroids days can be shortened with improvement in clinical, laboratory and radio-imaging parameters with improved quality of life of TBM patients and reduced days of hospital stay by using pulse therapy of Methyl Prednisolone. The strength of this study is that it provides a novel idea to use steroids in TBM patients for shorter period, so that adverse effect of long term use of steroids can be minimised. In both groups mortality rate at the initial stage of reporting were similar. But limitation of this study is that our study was of very short period of time with small sample size. Long term study of morbidity and mortality is the further suggested need.

For validation of this study, further large prospective studies with larger sample size will be required for better evaluation, so that TBM patients can be promptly diagnosed and better managed.

\section{REFERENCES}

1. Tandon PN, Bhatia R, Bhargava S. Tuberculous meningitis. In: Harris AA editor(s). Handbook of Clinical Neurology. Vol. 8, Amsterdam: Elsevier Science Publishers, 1988:195-226.

2. Prasad K, Singh MB, Ryan H, 2016. Corticosteroids for managing tuberculous meningitis. Cochrane Database Syst Rev 4: 1-64.

3. Centers for Disease Control and Prevention. Treatment of Tuberculosis, American Thoracic Society, CDC, and Infectious Diseases Society of America. MMWR 2003;52(RR-11):1-77.

4. Thwaites G, Fisher M Hemingway $C$, Scott $G$, Solomon T Innes J, British Infection Society. British Infection Society guidelines for the diagnosis and treatment of tuberculosis of the central nervous system in adults and children. Journal of Infection 2009;59(3):167-87.

5. Working Group of the Clinical Practice Guideline on the Diagnosis, Treatmen and Prevention of Tuberculosis. Centro Cochrane Iberoamericano (Iberoamerican Cochrane Centre), coordinator. Clinical Practice Guideline 
on the Diagnosis, Treatment and Prevention of Tuberculosis. Quality Plan for the Spanish National Healthcare System of the Spanish Ministry for Health, Social Policy and Equality: Agència d'Informació, Avaluació i Qualitat en Salut de Catalunya (AIAQS - Agency for Information, Evaluation, and Quality in Health of Catalonia). Ministry of Science and Innovation, Spain, 2010.

6. National Institute for Health and Care Excellence (NICE). Tuberculosis: Clinical diagnosis and management of tuberculosis, and measures for its prevention and control. NICE clinical guidelines 117. Manchester: NICE, March 2011.

7. Wang JT, Hung CC, Sheng WH, Wang JY, Chang SC, Luh KT. Prognosis of Tuberculosis meningitis in adults in the era of modern antiTuberculosis chemotherapy. J Microbiol Immunol Infect. 2002;35:215-22.

8. Lu CH, Chang WN, Chang HW. The prognostic factors of adult Tuberculosis meningitis. Infection. 2001;29:299-304.

9. Misra UK, Kalita J, Roy AK, Mandal SK, Srivastava M. Role of clinical, radiological, and neurophysiological changes in predicting the outcome of Tuberculosis meningitis: a multivariable analysis. J Neurol Neurosurg Psychiatry. 2000;68:300-03.

10. Thwaites GE, Chau TT, Stepniewska K, Phu NH, Chuong LV, Sinh DX, et al. Diagnosis of adult tuberculous meningitis by use of clinical and laboratory features. Lancet 2002;360(9342):1287-92.

11. Chotmongkol V, Jitpimolmard S, Thavornpitak Y. Corticosteroid in tuberculous meningitis. Journal of the Medical Association of Thailand 1996;79(2):83-90.

12. Girgis NI, Farid Z, Kilpatrick ME, Sultan Y, Mikhail IA. Dexamethasone adjunctive treatment for tuberculous meningitis. Pediatric Infectious Disease Journal 1991;10(3):179-83.

13. Kumarvelu S, Prasad K, Khosla A, Behari M, Ahuja GK. Randomized controlled trial of dexamethasone in tuberculous meningitis. Tubercle and Lung Disease 1994;75(3):203-7.

14. Prasad K, Volmink J, Menon GR. Steroids for treating tuberculous meningitis. Cochrane Database of Systematic Reviews 2006, Issue 1. [DOI: 10.1002/14651858.CD002244.pub2],

15. Schoeman JF, Van Zyl LE, Laubscher JA, Donald PR. Effect of corticosteroids on intracranial pressure, computed tomographic findings, and clinical outcome in young children with tuberculous meningitis. Pediatrics 1997;99(2):226-31.

16. Lardizabal DV, Roxas AA. Dexamethasone as adjunctive therapy in adult patients with probable TB meningitis stage II and stage III: An open randomised controlled trial. Philippines Journal of Neurology 1998;4:4-10.

17. Malhotra HS, Garg RK, Singh MK, Agarwal A, Verma R. Corticosteroids (dexamethasone versus intravenous methylprednisolone) in patients with tuberculous meningitis. Annals of Tropical Medicine and Parasitology 2009; 103(7):625-34

18. Thwaites GE, Nguyen DB, Nguyen HD, Hoang TQ, Do TT, Nguyen TC, et al. Dexamethasone for the treatment of tuberculous meningitis in adolescents and adults. New England Journal of Medicine 2004;351(17):1741-51.

19. Vimal Kumar Paliwal, Animesh Das, Sucharita Anand and Prabhakar Mishra. Intravenous Steroid Days and Predictors of Early Oral Steroid Administration in Tuberculous Meningitis: A Retrospective Study. Am. J. Trop. Med. Hyg., 101(5), 2019, pp. 1083-1086.

20. George EL, Iype T, Cherian A, Chandy S, Kumar A, Balakrishnan A, et al. Predictors of mortality in patients with meningeal tuberculosis. Neurol India. 2012;60:18-22.

21. British Medical Research Council. Streptomycin treatment of Tuberculosis meningitis. Lancet. 1948; 1:582-96.

22. Suran K, Pushpa S. Pulse therapy - A newer approach. Indian J Multidiscip Dent [serial online] 2017; 7:41-4. https://www.ijmdent.com/text.asp? 2017/7/1/41/209281.

23. Schimmer BP Parker KI. Adrenocorticotropic hormones; adrenocortical steroids and their synthetic analogs; inhibitors of the synthesis and actions of adrenocortical hormones. In: Brunton LL, Lazo JS, Parker KL, editors. Goodman and Gilman's the Pharmacological Basis of Therapeutics. 11th ed. New York: McGraw-Hill Professional; 2006. p. 1587-612.

24. Feldman S, Behar AJ, Weber D. Experimental tuberculous meningitis in rabbits. 1. Results of treatment with antituberculous drugs separately and in combination with cortisone. A. M. A. Archives of Pathology 1958;65(3):343-54.

25. Parsons M. Tuberculous Meningitis: Tuberculomas and Spinal Tuberculosis A Handbook for Clinicians (Oxford Medical Publications). 2nd Edition. Oxford: Oxford University Press, 1988:32-62.

26. Alarcón F, Escalante L, Pérez Y, Banda H, Chacón G, Dueñas G. Tuberculous meningitis. Short course of chemotherapy. Archives of Neurology 1990;47(12):1313-7.

27. Jacobs RF, Sunakorn P. Tuberculous meningitis in children: an evaluation of chemotherapeutic regimens. American Review of Respiratory Disease 1990;141 Suppl:A337.

28. Jacobs RF, Sunakorn P, Chotpitayasunonah T, Pope S, Kelleher K. Intensive short course chemotherapy for tuberculous meningitis. Pediatric Infectious Disease Journal 1992;11(3):194-8. Jacon-1990-92.

29. Ramachandran P, Duraipandian M, Nagarajan M, Prabhakar R, Ramakrishnan CV, Tripathy SP. Three chemotherapy studies of tuberculous meningitis in children. Tubercle 1986;67(1):17-29. 